University of Nebraska - Lincoln

DigitalCommons@University of Nebraska - Lincoln

USDA National Wildlife Research Center - Staff Publications
U.S. Department of Agriculture: Animal and Plant Health Inspection Service

June 2002

\title{
Caffeine as a repellent for slugs and snails
}

Robert G. Hollingsworth

US Pacific Basin Agricultural Research Center, USDA-Agricultural Research Service

John W. Armstrong

US Pacific Basin Agricultural Research Center, USDA-Agricultural Research Service

Earl Campbell

USDA-APHIS-WS-National Wildlife Research Center

Follow this and additional works at: https://digitalcommons.unl.edu/icwdm_usdanwrc

Part of the Environmental Sciences Commons

Hollingsworth, Robert G.; Armstrong, John W.; and Campbell, Earl, "Caffeine as a repellent for slugs and snails" (2002). USDA National Wildlife Research Center - Staff Publications. 470.

https://digitalcommons.unl.edu/icwdm_usdanwrc/470

This Article is brought to you for free and open access by the U.S. Department of Agriculture: Animal and Plant Health Inspection Service at DigitalCommons@University of Nebraska - Lincoln. It has been accepted for inclusion in USDA National Wildlife Research Center - Staff Publications by an authorized administrator of DigitalCommons@University of Nebraska - Lincoln. 


\section{Caffeine as a repellent for slugs and snails}

\section{At high concentrations this stimulant becomes a lethal neurotoxin to garden pests.}

$\mathrm{M}$ ost commercial products for snail and slug control contain either metaldehyde or methiocarb as the active ingredient $t^{1}$, the residues of which are not permitted in food crops in the United States ${ }^{2}$. We have discovered that solutions of caffeine are effective in killing or repelling slugs and snails when applied to foliage or the growing medium of plants. Because caffeine is a natural product and is classified by the US Food and Drug Administration as a GRAS ('generally recognized as safe') compound ${ }^{3}$, it has potential as an environmentally acceptable alternative toxicant for the control of slugs and snails on food crops.

While field-testing caffeine as a toxicant against an introduced frog pest that infests potted plants in Hawaii, we discovered that large slugs were killed by spray applications containing 1-2\% caffeine. To test whether caffeine solutions could be used to remove or kill large slugs that attack potted plants, we allowed Veronicella cubensis (Pfeiffer) to bury themselves in the soil in the pots, and then thoroughly wetted the soil with a $2 \%$ caffeine solution. After $3.5 \mathrm{~h}$, only $25 \%$ of the slugs remained in the soil; after $48 \mathrm{~h}$, all slugs had left the soil and $92 \%$ were dead.

We tested the effect of caffeine on slugs in choice and no-choice feeding tests. Leaves of 'Napa' cabbage were dipped in caffeine solution, drip-dried and then placed in ventilated, 2-litre plastic containers (Fig. 1). In no-choice tests over a 4-day period, the weight of cabbage consumed by the slugs exposed to caffeine relative to controls was reduced by $9,19,29$ and $39 \%$ for caffeine treatments of $0.01,0.1,0.5$ and $2 \%$, respectively.

Similarly, in choice tests over a 4-day period, consumption of treated cabbage leaves was reduced by $-11,62,77$ and $64 \%$ for the same concentrations. H owever, total cabbage consumption (that is, feeding on treated and untreated leaves) was reduced by $24,24,14$ and $28 \%$, respectively. We conclude that slugs can discriminate between treated and untreated leaves, and that caffeine significantly reduces feeding at a concentration of only $0.01 \%$.

To test the effect of caffeine on snails, we treated mature orchid snails (Zonitoides arboreus (Say); about $3 \mathrm{~mm}$ in diameter) topically with caffeine solutions in Petri dishes and examined them under a dissecting microscope to determine their heart rates. One hour after treatment, the heart rates of snails exposed to $0.01 \%$ caffeine were raised, whereas those of snails treated with $0.1,0.5$ or $2 \%$ caffeine were reduced (Fig. 2a). After $24 \mathrm{~h}$, heart contractions

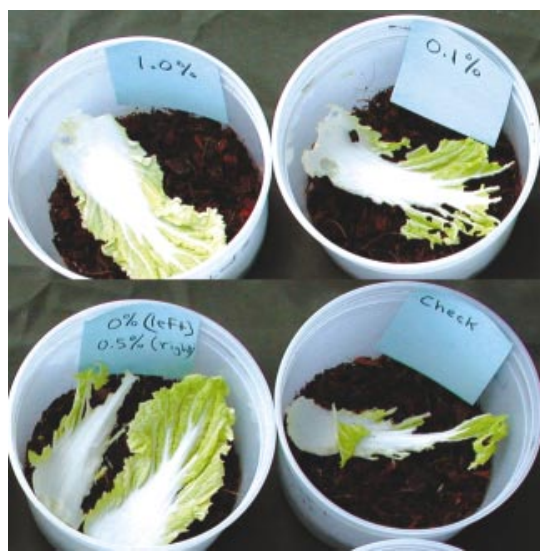

Figure 1 Repulsion of slugs (Veronicella cubensis (Pfeiffer)) by caffeine-sprayed leaves. Results pictured (clockwise, from top left) are for no-choice treatments using 1.0, 0.1 and $0 \%$ caffeine, and for a choice test with 0 (left leaf) and $0.5 \%$ caffeine. Caffeine treatment causes slugs to avoid the leafy parts of the cabbage.

were weak and irregular in snails treated with caffeine concentrations of $0.1 \%$ or more, and all snails treated with 0.5 or $2 \%$ caffeine were dead after $96 \mathrm{~h}$ (Fig. 2b).

We then carried out two greenhouse tests in which caffeine solutions were applied to the growing medium of potted orchids infested with $Z$. arboreus. In the first test, 1 and $2 \%$ solutions of caffeine were associated with 60 and 95\% mortality, respectively (control mortality averaged $10 \%)$. In the second, larger test, a $2 \%$ solution of caffeine proved to be more effective in reducing the presence of snails than a solution of $0.195 \%$ metal dehyde, the commercial standard for orchid-snail treatment. Over 30 days, 5 snails were extracted from the medium treated with caffeine, whereas 43 and 35 snails were collected from media treated with water (control) and metaldehyde, respectively.

Although caffeine has been used to study ion transport and the physiological function of nerves and muscles in molluscs and insects ${ }^{4-7}$, its toxicological effects on slugs and snails have escaped attention. Caffeine has been proposed as a potential pesticide and pesticide synergist, but only with reference to insect control ${ }^{8,9}$.

We do not know how caffeine kills slugs and snails. Physiological studies of mollusc neurons indicate that it releases calcium from internal stores, thereby increasing the duration of action-potential plateaus $s^{6,10}$. We found that large slugs placed on loose soil and sprayed with a 1 or $2 \%$ solution of caffeine responded with uncoordinated writhing; the only survivors were the few that were able to burrow into the soil soon after treatment.

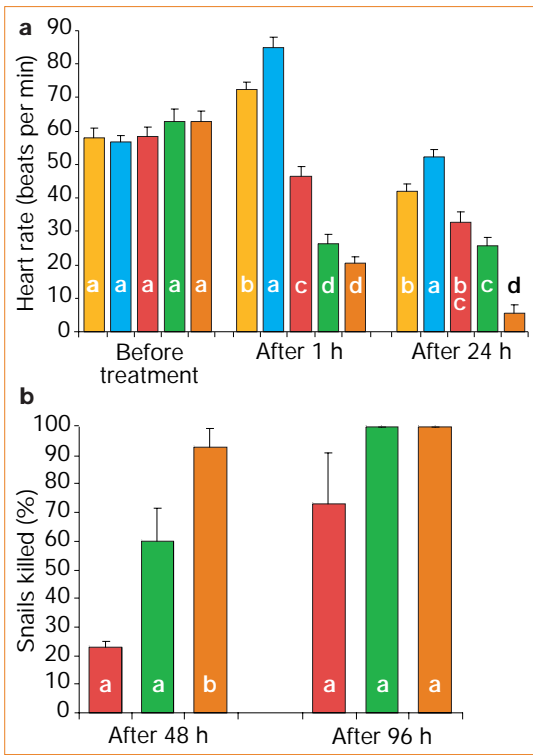

Figure 2 Effect of caffeine on the orchid snail Zonitoides arboreus (Say). a, Heart rates before and after treatment with different concentrations of caffeine. Bars (left to right in each set): $0,0.01$, $0.1,0.5,2.0 \%$ solutions of caffeine. $\mathbf{b}$, Mortality induced by higher doses of caffeine. Bars (left to right in each set): 0.1, 0.5, $2 \%$ solutions of caffeine. Error bars represent 1 s.e.m. Each treatment of five snails on filter paper in a Petri dish (three dishes) involved wetting the animals and paper with $1 \mathrm{ml}$ caffeine solution or distilled water (control). Heart rates of snails in the same dish were averaged before ANOVA. The proportion of snails that died in each dish were arc-sine transformed ${ }^{12}$ before analysis, excluding control dishes and those containing $0.01 \%$ caffeine, in which no snails died. Within each time period and test, results labelled with the same letter(s) are not significantly different ( $\alpha=0.05$, Tukey's HSD; ref.13). Further details are available from the authors.

We anticipate that, in an agricultural environment, slugs and snails will be more susceptible to contact poisoning from caffeine than other animals such as arthropods. This is because caffeine is highly soluble in water ${ }^{11}$, an important component of the mucus produced by the locomotive 'foot' of molluscs.

In preliminary trials, we found that $2 \%$ caffeine does not damage the foliage of Dracaena, Anthurium, palms or orchids, but that it causes leaf yellowing on ferns, bromeliads and lettuce. This damage could be ameliorated by mixing caffeine with an appropriate agricultural polymer, which could also increase the water resistance of spray residues.

\section{Robert G. Hollingsworth*,} John W. Armstrong*, Earl Campbell†‡ *US Pacific Basin Agricultural Research Center, USDA-Agricultural Research Service, PO Box 4459, Hilo, Hawaii 96720, USA

e-mail: rholling@pbarc.ars.usda.gov 
†USDA-APHIS-WS-National Wildlife Research Center, Box 10880, Hilo, Hawaii 96721, USA $\ddagger$ Present address: US Fish and Wildlife Service, Box 50088, Honolulu, Hawaii 96850, USA

1. M artin, A. Outlook Agric. 20, 167-174 (1991).

2. US Code of Federal Regulations. Title 40 - Protection of Environment (40CFR180.523) 479 (US Government, 2001).

3. US Code of Federal Regulations. Title 21 - Food and Drugs (21CFR182) 455 (US Government, 2001).

4. Fahim, M. A. \& Usherwood, P. N. R. J. N eurobiol. 14, 391-397 (1983)

5. M offett, D. F., Smith, C. J. \& Green, J. M. Comp. Biochem. Physiol. 75, 305-310 (1983)

6. Ahmed, I. A., Hopkins, P. M. \& Winlow, W. Gen. Pharmacol

\section{Development}

\section{Early-pregnancy origins of low birth weight}

ow birth weight is a significant cause of morbidity and mortality among new-

borns, and may result from impaired placental function during the first trimester of pregnancy ${ }^{1}$. Here we show that the risk of delivering a low-birth-weight baby at term after an uncomplicated pregnancy varies with maternal circulating concentrations of a placental protein, pregnancyassociated plasma protein-A (PAPP-A) in the first 10 weeks after conception. Poor fetal growth may therefore already have been determined by the time obstetric monitoring begins after completion of the first trimester.

PAPP-A acts as a protease on the binding proteins of insulin-like growth factor $(I G F)^{2,3}$ and may therefore increase the known stimulatory effects of placental $\mathrm{IGFs}^{4}$. Circulating concentrations of PAPP-A increase during the first three months of pregnancy, and this protein is highly expressed in trophoblasts. We therefore investigated a possible link between the birth weight of a baby at term and maternal levels of PAPP-A during the first trimester. We determined the specificity of associations with PAPP-A by comparing it with the free $\beta$-subunit of human chorionic gonadotrophin $(\beta-C G)$, another trophoblast-derived protein whose circulating levels change in the first trimester ${ }^{6}$ but which is functionally unrelated to the IGF system.

As part of a prospective, multicentre, non-interventional cohort study, we obtained serum from 4,288 women at 8-12 weeks of gestation (dated by ultrasound, equivalent to 6-10 weeks after conception), who ultimately had uncomplicated singleton pregnancies and delivered normal, live babies at full term. We had complete data for these women on maternal age, parity, height, body-mass index, race and smoking status.

Serum levels of PAPP-A and free $\beta-C G$ were measured using a Kryptor immunoassay analyser (Brahms Diagnostica) and converted to multiples of the appropriate
28, 245-250 (1997).

7. Cook, B. J. \& Holman, G. M. Comp. Biochem. Physiol. 67, $115-120(1980)$

8. Nathanson, J. A. Science 226, 184-187 (1984).

9. Wilkins, R. M., Saleem, M. A. \& Candasamy, R. Pestic. Sci. 43, 321-331 (1995).

10. Ahmed, I. A., Hopkins, P. M . \& Winlow, W. Comp. Biochem Physiol. 105, 363-372 (1993).

11. Windholz, M . (ed.) The M erck Index 9th edn (M erck, Rahway, New Jersey, 1976)

12. Steel, R. G. D. \& Torrie, J. H. Principles and Procedures of Statistics (M cGraw-Hill, N ew York, 1980).

13. SAS/STAT U ser's Guide 6.03 Chs 20, 24 (SAS Institute, Cary, North Carolina, 1988)

Competing financial interests: declared none.
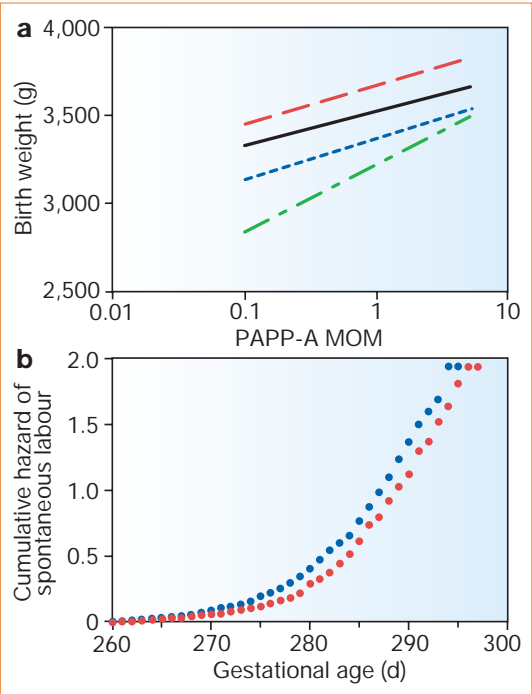

Figure 1 Association between pregnancy-associated plasma protein-A (PAPP-A), birth weight at 38-41 weeks of gestation and timing of labour at full term. a, Eventual birth weight plotted against PAPP-A multiples of the median (MOM; on a $\log _{10}$ scale) from a linear regression analysis. Curves (from bottom to top) represent gestational ages of 38, 39, 40 and 41 weeks. Coefficients $(95 \%$ $\mathrm{Cl})$ for change in birth weight associated with a one $\log _{10}$ unit change in PAPP-A MOM: 38 weeks, 380 (209-552); 39 weeks, 231 (113-349); 40 weeks, 196 (104-289); 41 weeks, 221 (112-331); $P<0.0001$ in each case. Coefficients were virtually unchanged after adjusting for age, parity, body-mass index, height, smoking status and race. $\mathbf{b}$, Cumulative hazard (Nelson-Aelen cumulative hazard function ${ }^{10}$ ) of spontaneous labour on each day of gestation at full term, comparing the lowest (top curve) and highest (bottom curve) quintiles of first-trimester PAPP-A MOMs. Univariate comparison, $P=0.0003$ (log rank test).

gestational median ( $M O M$ ), corrected for smoking status ${ }^{7}$ and maternal weight ${ }^{8}$.

There was a greater proportion of lowbirth-weight infants (under 2,500 g) delivered to women with a first-trimester PAPP-A concentration in the lowest $5 \%$ ( 9 out of 201 , $4.5 \%$ ) compared with other women (65 out of $4,087,1.6 \% ; P=0.002)$. Using multivariate logistic regression (adjusting for maternal height, race, body-mass index, smoking status and elective delivery), a one $\log _{10}$ unit increase in first trimester PAPP-A MOM (roughly equivalent to the range from the 1st to the 99th percentile) was associated with an $80 \%$ reduction in the risk of a low-birth- weight baby (adjusted odds ratio, 0.2; 95\% $\mathrm{Cl}, 0.1-0.6 ; \mathrm{P}=0.002$ ). In contrast, there was no significant independent relationship in the case of free $\beta$-CG (adjusted odds ratio, $0.6 ; 95 \% \mathrm{Cl}, 0.2-1.3 ; \mathrm{P}=0.17$ ).

The factors that determine variation in birth weight are fetal growth and the duration of pregnancy. We examined the relationship between PAPP-A concentration and fetal growth using multiple linear-regression analysis, and identified a strong, positive correlation between first-trimester levels of PAPP-A and eventual birth weight at 38-41 weeks of gestation (Fig. 1a). There was no strong association between free $\beta-C G$ levels and birth weight at the same gestational age.

The relationship between first-trimester concentrations of PAPP-A or free $\beta-C G$ and the timing of labour at full term was determined using time-to-event analysis ${ }^{9}$. Vaginal delivery after non-induced labour was taken as the event and all other modes of delivery were treated as censored. Lower concentrations of PAPP-A during the first trimester were associated with an earlier onset of spontaneous labour at full term (Fig. 1b).

In a multivariate proportional hazards model, there was a strongly additive and inverse relationship between levels of PAPP-A and free $\beta-C G$, and the likelihood of spontaneous labour on any given day of gestation at full term (adjusted hazard ratio for a one $\log _{10}$ unit change in MOM $(95 \%$ $\mathrm{Cl})$ : PAPP-A, 0.81 (0.69-0.96), $P=0.003$; free $\beta-C G, 0.79(0.69-0.91), P<0.001)$.

The association between PAPP-A levels, fetal growth and the timing of labour is biologically plausible, as PAPP-A is highly expressed in first-trimester trophoblasts ${ }^{5}$ and may be responsible for activation of IGFs. Our results indicate that the risk of delivering a low-birth-weight baby at full term may be determined by the placental activity of I GFs in very early pregnancy.

Gordon C. S. Smith*, Emily J. Stenhouset, Jennifer A. Crossleył, David A. Aitken‡, Alan D. Cameront, J. Michael Connorł *D epartment of O bstetrics and Gynaecology, University of Cambridge, The Rosie H ospital, Robinson Way, Cambridge CB2 2Q Q, UK e-mail: gcss2@cam.ac.uk

tD epartment of Fetal M edicine, The Q ueen M other's H ospital, Glasgow G3 8SJ, UK ‡Institute of M edical Genetics, Yorkhill N HS Trust, Glasgow G3 8S), UK

\footnotetext{
1. Smith, G. C. S., Smith, M. F. S., M cN ay, M . B. \& Fleming, J. E. E. N. Engl. J. M ed. 339, 1817-1822 (1998)

2. Lawrence, J. B. et al. Proc. N atl Acad. Sci. USA 96, 3149-3153 (1999)

3. Laursen, L. S. et al. FEBS Lett. 504, 36-40 (2001).

4. Rutanen, E. M. Curr. O pin. Obstet. Gynecol. 12, 163-168 (2000).

5. Overgaard, M. T. et al. Biol. Reprod. 61, 1083-1089 (1999).

6. Ozturk, M. et al. Endocrinology 120, 549-558 (1987).

7. Spencer, K. Prenat. Diagn. 19, 1065-1066 (1999).

8. Neveux, L. M., Palomaki, G. E., Larrivee, D. A., Knight, G. J. \& Haddow, J. E. Prenat. Diagn. 16, 1115-1119 (1996).

9. Smith, G. C. S. Hum. Reprod. 16, 1497-1500 (2001)

10. Hosmer, D. W. \& Lemeshow, S. Applied Survival Analysis (Wiley, New York, 1999).

Competing financial interests: declared none.
} 